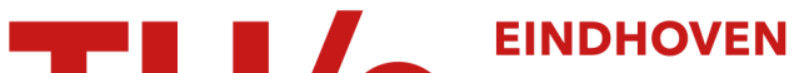 UNIVERSITY OF TECHNOLOGY
}

\section{Emission of microoorganisms from biofilters}

Citation for published version (APA):

Ottengraf, S. P. P., \& Konings, J. H. G. (1991). Emission of microoorganisms from biofilters. Bioprocess Engineering, 7(1-2), 89-96. https://doi.org/10.1007/BF00383584

DOI:

10.1007/BF00383584

Document status and date:

Published: 01/01/1991

\section{Document Version:}

Publisher's PDF, also known as Version of Record (includes final page, issue and volume numbers)

\section{Please check the document version of this publication:}

- A submitted manuscript is the version of the article upon submission and before peer-review. There can be important differences between the submitted version and the official published version of record. People interested in the research are advised to contact the author for the final version of the publication, or visit the $\mathrm{DOI}$ to the publisher's website.

- The final author version and the galley proof are versions of the publication after peer review.

- The final published version features the final layout of the paper including the volume, issue and page numbers.

Link to publication

\section{General rights}

Copyright and moral rights for the publications made accessible in the public portal are retained by the authors and/or other copyright owners and it is a condition of accessing publications that users recognise and abide by the legal requirements associated with these rights.

- Users may download and print one copy of any publication from the public portal for the purpose of private study or research.

- You may not further distribute the material or use it for any profit-making activity or commercial gain

- You may freely distribute the URL identifying the publication in the public portal.

If the publication is distributed under the terms of Article $25 \mathrm{fa}$ of the Dutch Copyright Act, indicated by the "Taverne" license above, please follow below link for the End User Agreement:

www.tue.nl/taverne

\section{Take down policy}

If you believe that this document breaches copyright please contact us at:

openaccess@tue.nl

providing details and we will investigate your claim. 


\title{
Emission of microorganisms from biofilters
}

\author{
S. P.P. Ottengraf, Eindhoven, J. H. G. Konings, Geleen, The Netherlands
}

\begin{abstract}
Experiments are reported on the discharge of microbial germs by biofilter systems used for the treatment of waste gases containing volatile organic compounds. The systems investigated concern six full-scale filter installations located in the Netherlands in several branches of industry, as well as a laboratory-scale installation used for modelling the discharge process. It is concluded that the number of microbial germs (mainly bacteria and to a much smaller extent moulds) in the outlet gas of the different full scale biofilters varies between $10^{3}$ and $10^{4} \mathrm{~m}^{-3}$, a number which is only slightly higher than the number encountered in open air and of the same order of magnitude encountered in indoor air. It is furthermore concluded that the concentration of microorganisms of a highly contaminated inlet gas is considerably reduced by the filtration process. On the basis of the experiments performed in the laboratory-scale filter bed, it is shown that the effect of the gas velocity on the discharge process results from two distinctive mechanisms: capture and emission. A theoretical model is presented describing the rate processes of both mechanisms. The model presented and the experimentally determined data agree rather well.
\end{abstract}

List of symbols

$\begin{array}{ll}a_{s} & \mathrm{~m}^{-1} \\ C & \mathrm{~m}^{-3} \\ C_{e}, C_{i} & \mathrm{~m}^{-3}\end{array}$

CFU -

$d_{c}, d_{m} \quad \mathrm{~m}$

D m

$\begin{array}{ll}E & -\end{array}$

$\begin{array}{ll}k_{c} & \mathrm{~m} \\ \mathrm{~s}^{-1}\end{array}$

$k_{e} \quad \mathrm{~m}^{-3}$

$\begin{array}{ll}k_{e} & - \\ r & \mathrm{~m}^{-3} \mathrm{~s}^{-1}\end{array}$ $r_{e}, r_{e} \quad \mathrm{~m}^{-3} \mathrm{~s}^{-1} \quad \begin{aligned} & \text { capture and emission rate per unit of bed- } \\ & \text { volume }\end{aligned}$

$R e=\quad-\quad \frac{\varepsilon}{(1-\varepsilon)} \frac{\varrho u d_{c}}{\mu}$ Reynolds number

$S_{t}=\quad-\quad \frac{\varrho_{m} u d m^{2}}{9 \mu d_{c}}$ Stokes number

$u \quad \mathrm{~m} \mathrm{~s}^{-1} \quad$ superficial gas velocity

$u_{m} \quad \mathrm{~m} \mathrm{~s}^{-1} \quad$ superficial gas velocity at which $C_{e}=C_{i}$

Greek symbols

$\begin{array}{ll}\varepsilon & - \\ \varrho & \mathrm{kg} \mathrm{m}^{-3}\end{array}$ specific area of the packing material microbial gas phase concentration microbial concentration in the exit and inlet

colony-forming-units resp.

single particle target efficiency bed height

first order capture rate constant per unit of bedvolume

emission rate constant per unit of bedvolume number of observations

void fraction of the filter bed

density of the gas phase diameter of the filter bed

$$
\begin{array}{lll}
\varrho_{m} & \mathrm{~kg} \mathrm{~m}^{-3} & \begin{array}{l}
\text { density of captured particle } \\
\text { dynamic gas phase viscosity }
\end{array} \\
\mu & \mathrm{Pa} \mathrm{s} & 1-\frac{C_{e}}{C_{i}} \text { filter bed efficiency }
\end{array}
$$

\section{Introduction}

Since the early sixties biological methods have been employed for the purification of waste gases containing volatile organic pollutants. At the outset, biofiltration as a technology for air pollution control, was mainly used for odour abatement in wastewater treatment plants, composting works, etc. Nowadays there is a clear trend to apply biofiltration on a much broader scale in different branches of the process industry and the application of and interest in biological gas treatment systems is rapidly increasing.

Microbial purification processes are based upon the ability of many microorganisms (generally bacteria, and to a small extent moulds and yeasts) to degrade a variety of organic compounds. Under aerobic conditions, these organisms are able to oxidize the compounds concerned into mineral endproducts (e.g. $\mathrm{CO}_{2}, \mathrm{H}_{2} \mathrm{O}$ etc.). Part of the organic compounds is transformed into new cell material.

In a biofilter the waste gas is forced to rise through a layer of biologically active packing material with a relatively high specific area $\left(300-1000 \mathrm{~m}^{-1}\right)$. Different types of packing material are used in practice e.g. compost, peat and mixtures of these natural materials with chips of wood, heather branches, polystyrene particles, etc. The quality of the filling material is characterized by mechanical and physical properties, e.g. the structure, the void fraction, the specific area, the flow resistance, the water buffering capacity and biological properties, e.g. the availability and provision of inorganic nutrients for the microorganisms, the specific biological activity, etc.

Until now, little research has been carried out on the subject of contamination of biologically treated air by microorganisms. The intention of the European Economic Community is to establish guidelines for working with bio- 
Table 1. Microbial concentration levels in different air compartments

\begin{tabular}{lcl}
\hline Air compartment & $\begin{array}{c}\text { Concentration } \\
\left(\mathrm{CFU} / \mathrm{m}^{3}\right)\end{array}$ & Lit. ref. \\
\hline Open air (coastal region) & $0.63 \cdot 10^{2}$ & {$[2]$} \\
Operating room, hospital & $4.6 \cdot 10^{2}$ & {$[3]$} \\
Open air (country side) & $10^{2}-10^{3}$ & {$[2]$} \\
Open air (town) & $7.6 \cdot 10^{2}$ & {$[4]$} \\
Canteen & $(4-9) \cdot 10^{2}$ & own \\
& & measurements \\
Cafeteria & $1.6 \cdot 10^{3}$ & {$[3]$} \\
Office & $(1.4-2.3) \cdot 10^{3}$ & {$[2,10]$} \\
Biotechnological laboratory & $4 \cdot 10^{3}$ & own \\
& & measurements \\
Sewage treatment plants & $10^{2}-10^{5}$ & {$[6-8]$} \\
Piggery, cow-house & $(7-13) \cdot 10^{4}$ & {$[2,5]$} \\
Poultry-house & $10^{4}-10^{5}$ & {$[2,9]$} \\
Compost factory & $10^{3}-10^{5}$ & {$[6]$} \\
\hline
\end{tabular}

logically active materials, and requires data to evaluate the risks of working with these materials. Moreover, in some branches of industry, particularly the food-, pharmaceuticaland fermentation industry, some fear exists for an increased contamination of raw materials and products with undesirable microorganisms during handling processes, due to a putatively high microbial emission by an installed biofilter.

Data dealing with the concentration of microorganisms in gasflows emitted by biofilter systems are very limited. Recent investigations on several biofilter systems have been carried out by Bardtke's group [1] in Germany.

In order to evaluate experimental data concerning microbial concentrations present in air, Table 1 lists some concentration levels which are met in different air compartments.

The investigations presented in this paper deal with the emission of microorganisms from biofilters and the influence of the gas velocity on the rate of emission. Experiments were carried out on a number of full-scale- and pilot plants, as well as laboratory-scale biofilters. Besides, a theoretical model will be presented, which describes the rate of microbial emission from biofilters and the mechanisms affecting it.

\section{Materials and methods}

\subsection{Determination of the CFU-number}

To estimate the number of microorganisms in the influentand effluent gas flows of a biofilter, samples were taken with a Millipore all-glass impinger [11]. According to this method a certain volume $\left(0.01-0.1 \mathrm{~m}^{3}\right)$ of air is drawn by a vacuumpump through a narrow capillary (internal diameter $1.2 \mathrm{~mm}$ ) into the impinger fluid at an air flow rate of approx. $1.7 \cdot 10^{-4} \mathrm{~m}^{3} / \mathrm{s}$. Due to the high air velocity in the capillary (ca. $150 \mathrm{~m} / \mathrm{s}$ ) a continuous gaschannel is created in the vessel beyond the nozzle of the capillary, and due to inertial forces microorganisms present in the air impinge on the humid glass bottom from which they are washed away by the surrounding impinger liquid.

The impinger vessel, containing $0.1 \mathrm{dm}^{3}$ of a physiological salt solution ( $8.5 \mathrm{~g} \mathrm{NaCl}$ per $\mathrm{dm}^{3}$ distilled water), is sterilized before use. The exact air volume, which has passed the apparatus during the sampling, is recorded by a gasflowmeter.

After the sampling the impinger liquid is diluted with $0.9 \mathrm{dm}^{3}$ of a sterile physiological salt solution and the standard membrane filter procedure is followed in order to determine the number of colony-forming-units (CFU). According to this method the microbial germs are separated by filtration on a membrane filter (porediameter $0.45 \mu \mathrm{m}$ ) which is put on a solid culture medium and incubated at room temperature during six days. The number of colonies are counted on the third and the sixth day and from this the CFU-number in the original air sample can directly be calculated. We used the ready-to-hand standard TTC "Nahrkartonscheiben" of Sartorius, as this solid culture medium is appropriate to a broad range of microorganisms. It will be evident that the CFU-number indicates that a colony which appears at the solid culture medium after incubation originates from a germ consisting of one or more cells.

From visual observations it was determined whether a colony developed consisted of bacteria or moulds.

\subsection{Processing of the experimental data}

Because of the lack of reproducibility, several samples were taken at one sample site. The data obtained from that sampling site were assumed to be distributed lognormally. Especially in the field of air sampling good results have been obtained in the lognormal processing of the obtained data [13-18]. This procedure starts from the fact that the logarithmic transformations of the obtained data are normally distributed. The geometric mean and the geometric standard deviation, being the two parameters by which the lognormal distribution curve is completely determined, are the antilogs of the mean and the standard deviation, respectively, of the logarithmically transformed data points.

Hence, the value of the geometric mean of the obtained data is considered to be the representative CFU-number for the concentration of microorganisms in the air at the sampling site concerned. With the use of common statistical analysis procedures it is in this way possible to detect significant differences between the CFU-number of the inlet- and outlet gasflow of a biofilter, for example.

\section{Experimental set-up}

\subsection{Full scale installations}

Experiments were carried out at six full-scale biofilters to determine the rate of microbial emission under practical conditions. Three of the filters investigated belong to the 
Table 2. Specifications of the full-scale plants

\begin{tabular}{|c|c|c|c|c|c|c|c|}
\hline $\begin{array}{l}\text { Code } \\
\text { number }\end{array}$ & Type & \multicolumn{3}{|c|}{ Packing material } & \multicolumn{3}{|c|}{ Waste gas source } \\
\hline 1 & Bioton & \multicolumn{3}{|c|}{ Compost-polystyrene } & \multicolumn{3}{|c|}{$\begin{array}{l}\text { Oriental food } \\
\text { processing }\end{array}$} \\
\hline II & Conventional & \multicolumn{3}{|c|}{$\begin{array}{l}\text { Compost } \\
\text { (coarsely structured) }\end{array}$} & \multicolumn{3}{|c|}{$\begin{array}{l}\text { Domestic sewage } \\
\text { treatment plant }\end{array}$} \\
\hline III & Bioton & \multicolumn{3}{|c|}{ Compost-polystyrene } & \multicolumn{3}{|c|}{$\begin{array}{l}\text { Flavour and } \\
\text { fragrance }\end{array}$} \\
\hline IV & Conventional & \multicolumn{3}{|c|}{ Peat-heather branches } & \multicolumn{3}{|c|}{ Destructor } \\
\hline $\mathrm{V}$ & Conventional & \multicolumn{3}{|c|}{ Peat-heather branches } & \multicolumn{3}{|c|}{ Destructor } \\
\hline VI & Bioton & \multicolumn{3}{|c|}{ Compost-polystyrene } & \multicolumn{3}{|c|}{$\begin{array}{l}\text { Industrial sewag } \\
\text { treatment plant }\end{array}$} \\
\hline \multirow{2}{*}{\multicolumn{2}{|c|}{ Process specifications }} & \multicolumn{6}{|c|}{ Code number installation } \\
\hline & & I & II & III & IV & V & VI \\
\hline \multicolumn{2}{|c|}{ Filter area, $\left[\mathrm{m}^{2}\right]$} & 24 & 25 & 14 & 300 & 225 & 20 \\
\hline \multicolumn{2}{|c|}{ Packing height, $[\mathrm{m}]$} & 1 & 0.75 & 1 & 1 & 1 & 1 \\
\hline \multicolumn{2}{|c|}{ Filter stages, $[-]$} & 2 & 1 & 2 & 1 & 1 & 1 \\
\hline \multicolumn{2}{|c|}{ Gasflow rate, $\left[10^{3} \mathrm{~m}^{3} / \mathrm{h}\right]$} & 9 & 0.75 & 3 & 60 & 30 & 8 \\
\hline \multicolumn{2}{|c|}{ Gas velocity, $[\mathrm{m} / \mathrm{h}]$} & 375 & 30 & 214 & 200 & 133 & 400 \\
\hline \multicolumn{2}{|c|}{$\begin{array}{l}\text { Water content } \\
\text { of packing, }[\% \mathrm{w} / \mathrm{w}]\end{array}$} & 39 & 30 & 40 & 45 & 51 & 55 \\
\hline \multicolumn{2}{|c|}{$\begin{array}{l}\text { Inlet gas temperature, } \\
{\left[{ }^{\circ} \mathrm{C}\right]}\end{array}$} & 30 & 18 & 45 & 20 & 27 & 15 \\
\hline \multicolumn{2}{|c|}{$\begin{array}{l}\text { Outlet gas temperature, } \\
{\left[{ }^{\circ} \mathrm{C}\right]}\end{array}$} & 30 & 19 & 43 & 21 & 23 & 15 \\
\hline \multicolumn{2}{|c|}{$\begin{array}{l}\text { Outside temperature, } \\
{\left[{ }^{\circ} \mathrm{C}\right]}\end{array}$} & 23 & 6 & 13 & 5 & -2 & 3 \\
\hline \multicolumn{2}{|c|}{ Pressure drop, [kPa] } & n.d. & $0.7-1$ & 20.45 & 0.18 & 0.36 & n.d. \\
\hline
\end{tabular}

n. d.: not determined

conventional open type filled with compost or a mixture of peat and heather branches, the other three belong to the closed type (trademark: Bioton) with a mixture of equal volumes of finely structured compost and polystyrene particles $\left(d_{c}: 3-5 \mathrm{~mm}\right)$. All the installations are located in the Netherlands and treat different kinds of waste gases. Some further specifications of the installations and process conditions are listed in Table 2.

\subsection{Laboratory-scale biofilter}

A laboratory-scale biofilter was used to model the system and to investigate the influence of the gas velocity on the microbial emission rate. The filter, schematically shown in Fig. 1, consisted of a quickfit glass column with an inner diameter of $15 \mathrm{~cm}$ and a filter height of $1 \mathrm{~m}$. At the bottom of the column a sieve plate was mounted to support the packing material consisting of a mixture of equal volumes finely structured compost and polystyrene particles $\left(d_{c}: 3-\right.$ $5 \mathrm{~mm}$ ). The package was inoculated with an activated sludge suspension from a municipal waste water treatment plant. To keep the humidity of the packing material at a desired

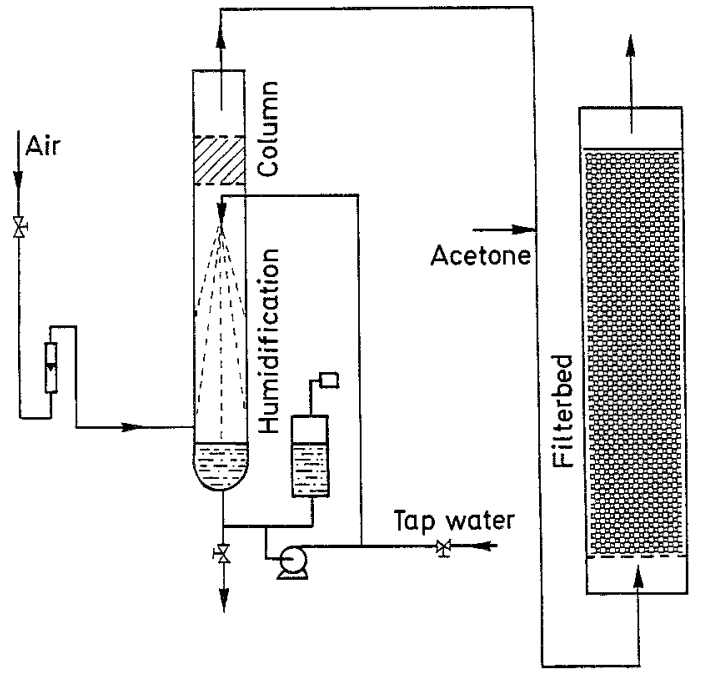

Fig. 1. Schematic representation of the laboratory-scale biofilter

level of $40-60 \%(\mathrm{w} / \mathrm{w})$, the influent air was humidified before entering the filterbed. A synthetic waste gas, with concentrations of up to $750 \mathrm{mg} / \mathrm{m}^{3}$ of acetone, was created by the continuous injection of this compound in the air stream. The advantage of using acetone as a contaminant is the ready microbial degradability of the component. Furthermore, acetone can be used by a broad range of microorganisms as their sole carbon- and energy source.

When no experiments were carried out at the filter bed, the system was continuously operated at standard conditions, being a superficial gas velocity of $200 \mathrm{~m} / \mathrm{h}$, room temperature and a gas inlet concentration of $750 \mathrm{mg} / \mathrm{m}^{3}$. At these conditions the stationary degree of conversion of the filter bed amounted to $80 \%$.

\section{Experimental results}

\subsection{The microbial emission by full-scale systems}

The CFU-number of bacteria and moulds emitted by the different full-scale filter beds are listed in Table 3.

From the data presented in Table 3 it can be concluded that the number of microbial germs in the outlet gas of the different biofilters varies between $10^{3}-10^{4} \mathrm{~m}^{-3}$, a number which is only slightly higher than the number encountered in open air and of the same order of magnitude encountered in indoor air (see Table 1). The presented data are of the same order as those measured in the German investigation [1].

Furthermore, it can be concluded that the concentration of microorganisms of a highly contaminated inlet gas is considerably reduced by the filtration process (installations no. IV and V). On the other hand, there is an extra contamination due to the filtration process at low CFU-numbers of the inlet gas (inst. no. III and VI). From this it is obvious that a biofilter may serve as a system of capture as well as a source of emission. 
Table 3. Microbial emission by full-scale filter beds

\begin{tabular}{|c|c|c|c|c|c|c|}
\hline \multirow{3}{*}{$\begin{array}{l}\text { Code number } \\
\text { filter installation }\end{array}$} & \multicolumn{6}{|c|}{ Microbial concentration $\left[\mathrm{CFU} / \mathrm{m}^{3}\right]$} \\
\hline & \multicolumn{3}{|c|}{ Inlet } & \multicolumn{3}{|c|}{ Outlet } \\
\hline & $\mathrm{n}$ & Bacteria & Moulds & $\mathrm{n}$ & Bacteria & Moulds \\
\hline I & & n.d. & n.d. & 12 & 1750 & 1180 \\
\hline II & & n.d. & n.d. & 12 & 4780 & 600 \\
\hline III & 6 & 933 & 302 & 12 & 1150 & 24 \\
\hline IV & 6 & $>2 \cdot 10^{4}$ & n.d. & 12 & 9350 & 30 \\
\hline $\mathrm{V}$ & 5 & 13900 & 5 & 10 & 6400 & 130 \\
\hline VI & 9 & 580 & 3 & 9 & 1020 & 19 \\
\hline
\end{tabular}

$\mathrm{n}$ : number of observations; n.d.: not determined

The data presented also show that the emitted concentrations are considerably affected by the structure of the packing material. Finely structured, homogeneous packing materials like the investigated compost-polystyrene mixtures (inst. no I, III and VI) emit lower CFU-numbers of bacteria than more inhomogeneous materials like coarsely structured compost and conventional mixtures of peat and heather branches (inst. no II, IV and V).

\subsection{Influence of the gas flow rate on microbial emission}

In a laboratory-scale filter bed, as outlined before, the influence of the gas flow rate on the rate of microbial emission was studied. During the sampling with the all-glass impinger the dosing of acetone into the inlet gas flow was interrupted.

In view of the rather constant inlet conditions of the synthetic waste gas and the laborious experimental manipulations, the determination of the CFU-numbers in the inlet gas was only performed in a restricted number of cases. The inlet CFU-number of bacteria of the synthetic waste gas usually varied between approx. 1500 and $2500 \mathrm{~m}^{-3}$. The results concerning the emitted number of germs in dependence on the superficial gas velocity are given in Table 4.

As can be seen from Table 4, the results have been gathered during an operational period of the filter bed of over six months. This explains the scattering of the observed data in the course of time.

Nevertheless, some interesting conclusions can be drawn from the data presented:

a) the number of discharged moulds is generally low compared to the number of bacteria. The discharged total numbers of germs encountered in the laboratory-scale filter bed are in rather good agreement with the emission data of full-scale installations provided with the same packing material.

b) the number of bacteria discharged at low values of the gas velocity is generally above the range of the CFU-inlet number and there is a clear trend of a decrease of the outlet concentration at increased values of the velocity. As already stated before, a biofilter may serve as a system of capture as well as a source of emision. Since the emission rate may
Table 4. Influence of the gas velocity on the microbial emission

\begin{tabular}{llllr}
$\begin{array}{l}\text { Time after } \\
\text { start-up } \\
{[\mathrm{d}]}\end{array}$ & $\begin{array}{l}\text { Number of } \\
\text { observations } \\
{[-]}\end{array}$ & $\begin{array}{l}\text { Superficial } \\
\text { gas velocity } \\
{[\mathrm{m} / \mathrm{h}]}\end{array}$ & $\begin{array}{l}\text { Outlet gas } \\
\text { concentration } \\
{\left[\mathrm{CFU} / \mathrm{m}^{3}\right]}\end{array}$ \\
\cline { 3 - 5 } & & & Bacteria & Moulds \\
\hline 30 & 6 & 162 & 3940 & 10 \\
30 & 6 & 314 & 2920 & 5 \\
30 & 6 & 459 & 2070 & 3 \\
37 & 6 & 238 & 3440 & 23 \\
37 & 6 & 436 & 1880 & 12 \\
37 & 6 & 634 & 1410 & 5 \\
67 & 5 & 238 & 1130 & 12 \\
67 & 5 & 436 & 930 & 18 \\
67 & 6 & 634 & 400 & 7 \\
107 & 6 & 158 & 6630 & 10 \\
107 & 6 & 238 & 2910 & 5 \\
129 & 6 & 79 & 3490 & 130 \\
129 & 5 & 158 & 2810 & 600 \\
129 & 6 & 238 & 1070 & 710 \\
198 & 8 & 119 & 2950 & 250 \\
198 & 8 & 555 & 1090 & 24 \\
\hline
\end{tabular}

Table 5. Capture by a sterile filter bed

\begin{tabular}{|c|c|c|c|c|c|c|}
\hline \multirow{3}{*}{$\begin{array}{l}\text { Time } \\
\text { after } \\
\text { start-up } \\
\text { [d] }\end{array}$} & \multirow{3}{*}{$\begin{array}{l}\text { Number } \\
\text { of obser- } \\
\text { vations } \\
{[-]}\end{array}$} & \multirow{3}{*}{$\begin{array}{l}\text { Superficial } \\
\text { gas velocity } \\
{[\mathrm{m} / \mathrm{h}]}\end{array}$} & \multicolumn{4}{|c|}{ Microbial concentration } \\
\hline & & & \multicolumn{2}{|l|}{ Inlet } & \multicolumn{2}{|c|}{ Outlet } \\
\hline & & & $\begin{array}{l}\text { Bac- } \\
\text { teria }\end{array}$ & Moulds & $\begin{array}{l}\text { Bac- } \\
\text { teria }\end{array}$ & Moulds \\
\hline 0 & 9 & 446 & 1610 & 22 & 810 & 140 \\
\hline 4 & 9 & 446 & 2390 & 190 & 1630 & 1 \\
\hline
\end{tabular}

probably be expected to increase at higher gas velocities, it will be obvious that the capture mechanism produces a more pronounced and inversed effect on the number of germs discharged at increased gas flow rates.

In order to verify the capture by the filtersystem, experiments were performed in a filter bed $(D=15 \mathrm{~cm})$ consisting of sterilized packing material with a bed height of $0.50 \mathrm{~m}$. In this way the serving of the bed as a source of microorganisms can be eliminated. The packing material consisted of equal volumes of lava particles $\left(d_{c}: 3-5 \mathrm{~mm}\right)$ and compost. Lava was chosen as an inert substitute for polystyrene, because the latter cannot be steam-sterilized without morphological changes. Sterilization of the packing material was carried out in an autoclave for $1 \mathrm{~h}$ at $120^{\circ} \mathrm{C}$.

The filter bed was packed immediately after the sterilization of the packing material, and air, containing airborne microorganisms was led through it, at a superficial gasvelocity of $446 \mathrm{~m} / \mathrm{h}$.

The experimental results are listed in Table 5. 


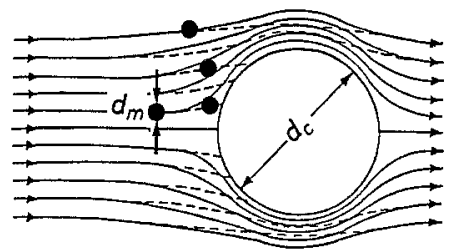

Inertial impaction
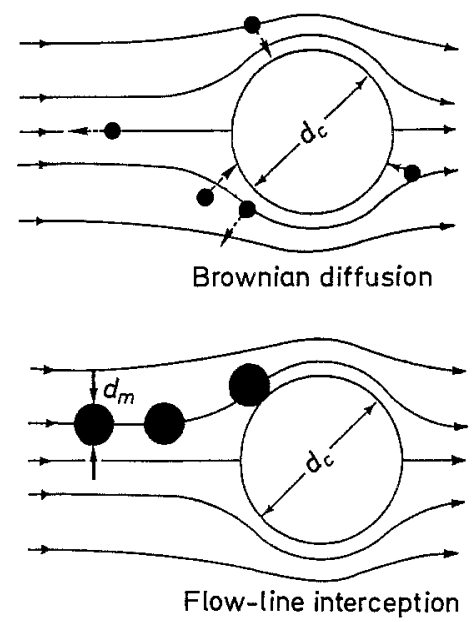

Fig. 2. Mechanisms of capture of dispersoid particles

Although the initially high amount of moulds in the outlet gas probably indicates insufficient sterilization conditions for spore killing, it can be concluded from the data presented in Table 5 that there is a considerable reduction of the number of bacteria due to capture by the filter bed.

\section{Theoretical discharge model}

The discharge of microorganisms by a biofilter bed is brought about by two simultaneous mechanisms: capture and emission.

\subsection{Capture}

Capture concerns with the removal or collection of solid dispersoids present in gases, due to impingement on the packed bed particles. When a dispersoid-laden gas impinges on a solid particle, the gas will be deflected around this particle, whereas the dispersoid particles by virtue of their greater inertia will tend to be collected on the surface of the body. Impingement is generally characterized in terms of the so-called target efficiency, which represents the fraction of dispersoids in a gas volume swept by a bed particle which will impinge on this particle. Capture of dispersoid particles in a granular packed bed is generally effected by three different mechanisms: 1. inertial deposition, 2. diffusional or Brownian deposition and 3. flow line interception. The mechanisms mentioned are visualized in Fig. 2.

A number of investigators have evaluated the relative contribution of each mechanism for dust particles and they agree that for dispersoid collection at sufficiently high veloc- ities, the predominant mechanism is inertial impaction. Brownian diffusion is only effective for particles in the submicron range $(<0.1-1 \mu \mathrm{m})$, where the velocity of the dispersoid particle relative to the collecting particle is very small $[19,20]$. Interception can be significant when the particle path is obstructed by a great many collecting particles of a diameter similar to that of the dispersoid [2].

The average size of individual microorganisms (bacteria and moulds) which are responsible for biodegradation in biofilters, and (clusters of) microorganisms freely dispersed in the gas phase is generally in the $\mu \mathrm{m}$ range. As a consequence of the gas velocities normally applied in biofilters $(0.01-0.15 \mathrm{~m} / \mathrm{s})$ and of the average size of the packing particles $(3-10 \mathrm{~mm})$, the combined effects of Brownian diffusion and interception are generally minor as compared to the inertial mechanism in the impingement of microorganisms in biofilter beds.

Several theoretical models for the removal of dispersoids in granular bed filters, consisting of equally sized spheres which are homogeneously distributed, have been suggested [e.g. 21, 22] . A combined overview can be found in a review of theoretical and experimental studies by Gutfinger et al. [23]. These models generally start from single particle target efficiency and the efficiency of the whole bed is found by integration over the entire granular bed. Moreover, single sphere target efficiency is generally assumed to be independent of the dispersoid concentration. This implies that collection is a first order process in dispersoid concentration [24] and may hence be regarded as a first order heterogeneous chemical reaction.

We accordingly propose for the capture rate in a biofilter that:

$r_{c}=k_{c} C$,

where:

$r_{c}=$ capture rate $\left(\mathrm{m}^{-3} \mathrm{~s}^{-1}\right)$;

$k_{\mathrm{c}}=$ first-order rate constant per unit of bed volume $\left(\mathrm{s}^{-1}\right)$; and

$C=$ number of concentration of germs in the gas phase $\left(\mathrm{m}^{-3}\right)$.

For a homogeneous filter bed consisting of equally sized spheres the capture rate constant $k_{c}$ is given by [24]:

$k_{c}=\frac{3 E u(1-\varepsilon)}{2 d_{c}}$,

where:

$E=$ single particle target efficiency (-);

$u=$ superficial gas velocity $(\mathrm{m} / \mathrm{s})$;

$\varepsilon=$ void fraction of the packed bed $(-)$; and

$d_{c}=$ diameter of collecting particle $(\mathrm{m})$

If the target efficiency is only due to inertial impaction, the relation of Thambimuthu [25] may be used:

$E=\left(1+\frac{0.06 \varepsilon}{S_{t}}\right)^{-3} \quad\left(\right.$ for $\left.S_{t}<0.02\right)$, 
where:

$S_{t}=$ Stokes number $=\frac{\varrho_{m} u d_{m}^{2}}{9 \mu d_{c}} ;$

$d_{m}=$ diameter of captured particle $(\mathrm{m})$;

$\varrho_{m}=$ density of captured particle $\left(\mathrm{kg} / \mathrm{m}^{3}\right)$; and

$\mu=$ dynamic gas phase viscosity $(\mathrm{Pa} \cdot \mathrm{s})$.

From Eqs. (2) and (3) it follows that:

$k_{c}=\frac{3(1-\varepsilon)}{2 d_{c}} \frac{u}{\left(1+\frac{0.06 \varepsilon}{S_{t}}\right)^{3}}$.

Since the structure of biofilter packing materials may deviate considerably from the idealized packed bed model, it is likely to combine physical constants of Eq. (4) into overall constants in order to describe the dependence of the capture rate constant on the gas velocity:

$k_{c}=a \frac{u}{(1+b / u)^{3}}$.

The constants $a$ and $b$ in Eq. (5) depend on the nature and structure of the packing material. The values of these constants have to be determined experimentally, but may roughly be estimated from Eq. (4).

\section{Example of application}

According to Eq. (1) the capture efficiency for a filter bed amounts to:

$\eta=1-\frac{C_{e}}{C_{i}}=1-\exp \left[-k_{c} \frac{H}{u}\right]$,

where:

$C_{e}, C_{i}=$ the number concentration of germs in the exit and entrance gas, resp. $\left(\mathrm{m}^{-3}\right)$; and

$H=$ the height of the filter bed (m).

From the experimental investigations on the sterile filter bed $(H=0.5 \mathrm{~m} ; u=446 \mathrm{~m} / \mathrm{h})$ and the data on the emitted number of bacteria presented in Table 5 , an average value of $k_{c}$ can be calculated according to Eq. (6) of approx. $0.1 \mathrm{~s}^{-1}$.

With $\varepsilon=0.3$ [26] and $d_{c}=4 \cdot 10^{-3} \mathrm{~m}$ it follows from Eq. (2) for the value of the target efficiency for a single collector particle at $u=446 \mathrm{~m} / \mathrm{h}$ that $E=2 \cdot 10^{-3}$. On the basis of this value the average size $d_{m}$ of bacterial germs in the gas phase can be estimated from Eq. (3). With $\varrho_{m}=10^{3} \mathrm{~kg} \mathrm{~m}^{-3}$ and $\mu=1.8 \cdot 10^{-5} \mathrm{~Pa} \cdot \mathrm{s}$, it follows that $d_{m}=4 \cdot 10^{-6} \mathrm{~m}$, which seems a rather reliable estimation taking the possibility of cluster formation of microbial germs into acount. From Eq. (4) it can be concluded that the capture rate is highly affected by the gas velocity, which is visualized in Fig. 3.

\subsection{Emission}

The growing amount of experimental investigations in the field of biofiltration has among others led to the develop-

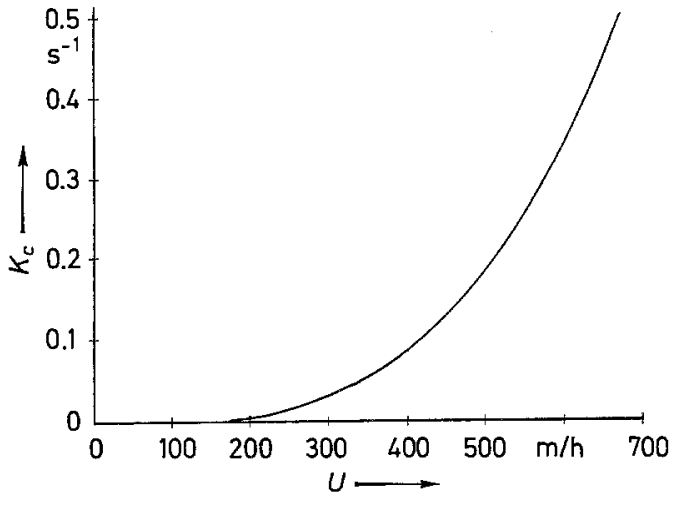

Fig. 3. The influence of the superficial gas velocity on the capture rate constant according to Eq. (4). $\left(\varepsilon=0.3 ; \varrho_{m}=10^{3} \mathrm{~kg} \mathrm{~m}^{-3} ; d_{m}=\right.$ $\left.4 \cdot 10^{-6} \mathrm{~m} ; d_{c}=4 \cdot 10^{-3} \mathrm{~m} ; \mu=1.8 \cdot 10^{-5} \mathrm{~Pa} \mathrm{~s}\right)$

ment of theoretical and practical models describing the performance of biofilters very well [e.g. 26]. These models are generally based upon the concept of a wet biolayer, mainly containing bacteria, which surrounds the packed bed particles. As a result of the flow field of the gas phase the biolayer is continuously exposed to shear stresses. By virtue of the shear stress at the gas-biolayer interface microorganisms are evolved from the biofilter, and transported by the gas.

The granular bed particles may in this way serve as a continuous source of microbial emission. In describing the rate of the emission process we assume the microbial flux from the biolayer to the gas phase to be proportional to the interfacial shear stress.

In order to create a sufficiently long residence time in view of microbial degradation, gas velocities generally applied in biofilters are relatively low $(0.01-0.10 \mathrm{~m} / \mathrm{s})$. Hence, Reynolds-numbers based upon the hydraulic diameter of the interstitial space in the bed $\left(\operatorname{Re}=\frac{\varepsilon}{(1-\varepsilon)} \frac{\varrho u d_{c}}{\mu}\right)$ are low, typically in the range between 10 and 100 . As a consequence, the flow regime of the gas phase can be regarded as laminar, which implies the interfacial shear stress is proportional to the superficial gas velocity.

If moreover the biolayer is considered as an inexhaustible source of emission and, consequently, a constant surfacial microorganism concentration is assumed, it follows on the basis of these considerations for the rate of emission per unit of bed volume:

$r_{E}=k_{e} a_{s} u$

where:

$k_{e}=$ emission rate constant per unit of bed volume $\left(\mathrm{m}^{-3}\right)$; and

$a_{\mathrm{s}}=$ specific area of the packing material $\left(\mathrm{m}^{-1}\right)$.

It is quite obvious that the emission rate constant $k_{e}$ will largely depend on physical and biological properties of the packing material and biolayer, respectively. Slime producing bacteria and hyphae of sporing moulds can be expected to 
show a completely different behaviour with respect to the emission process.

The further analysis will therefore be restricted to the emission of bacteria from the biolayer.

The rate expression according to Eq. (7) implies that in the absence of capture the increase of the concentration of (bacterial) germs in the gas passing the filter bed is equal to $\Delta C=C_{e}-C_{i}=k_{e} a_{s} H$ and is hence independent on the gas velocity.

It furthermore can be concluded that at low values of the gas velocity the rate of capture according to Eqs. (1) and (4) is proportional to $u^{4}$ and will, hence, be neglectable to the rate of emission. This phenomenon is probably responsible for the observed increase in bacterial concentration at low values of the gas velocity (see Table 4). To these aspects it will be returned further on.

\subsection{Simultaneous capture and emission}

Combining the mechanisms of capture and emission according to Eqs. (1) and (7), respectively, the axial bacterial concentration profile in a biofilter at steady state conditions is given by:

$-u \frac{\mathrm{d} C}{\mathrm{~d} h}+k_{e} a_{\mathrm{s}} u-k_{c} C=0$

with the boundary condition:

$h=0, \quad C=C_{i}$.

The outlet concentration $C_{e}$ follows from the solution of Eqs. (8) and (9) and is given by:

$C_{e}=\left(C_{i}-\frac{k_{e} a_{\mathrm{s}} u}{k_{\mathrm{c}}}\right) \exp \left(-\frac{k_{c} H}{u}\right)+\frac{k_{e} a_{s} u}{k_{c}}$.

From Eq. (10) it can be concluded that:

a) at a value of the gas velocity $u_{m}=\frac{k_{c}}{k_{e} a_{s}} C_{i}$, the outlet concentration just equals the inlet concentration. Consequently, two regions can be distinguished with respect to the gas velocity: a region of enrichment $\left(C_{e}>C_{i}\right)$ at $u<u_{m}$ and a region of impoverishment $\left(C_{e}<C_{i}\right)$ at $u>u_{m}$.

b) at low values of the gas velocity the increase in the concentration of the gas phase is mainly determined by the emission process. For a value of the gas velocity which approaches zero, it follows:

$u \rightarrow 0 ; \quad C_{e}-C_{i}=k_{e} a_{s} H$

Figure 4 shows the theoretical paths of the outlet concentration as a function of the gas velocity according to Eq. (10) at process conditions for the laboratory-scale filter bed outlined in IV $\cdot 2\left(1500 \mathrm{~m}^{-3}<C_{i}<2500 \mathrm{~m}^{-3} ; H=1 \mathrm{~m}\right)$. In the computing of these curves, gas velocity dependent $k_{c}$-values have been used as given in Fig. 3; the value of $k_{e} a_{s}$ $\left(1500 \mathrm{~m}^{-4}\right)$ has been obtained by curve-fitting of the experimental data presented in Table 4, which also have been plotted in Fig. 4.

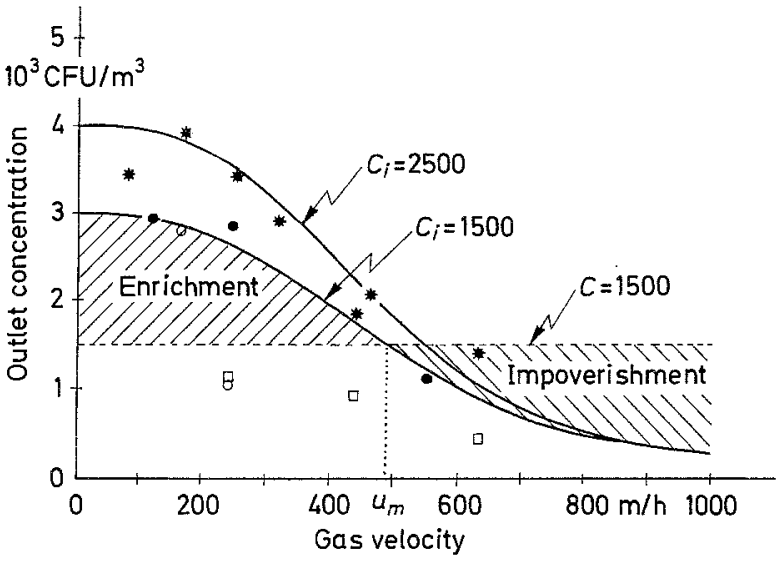

Fig. 4. The bacterial outlet concentration as a function of the superficial gas velocity at $C_{i}=1500$ and $2500 \mathrm{~m}^{-3}$. (Drawn curves have been computed according to Eq. (10) with $k_{e} a_{s}=1500 \mathrm{~m}^{-4}$ and $k_{c}$-values according to Fig. 3 ; data points according to Table 4)

From this it can be concluded that the theoretical model presented describes the experimental data rather well.

\section{Conclusions}

Microbial germs discharged by biofilters mainly consist of bacteria and to a minor extent of moulds. The concentration of microorganisms observed in the outlet gas of different full-scale filter installations is only slightly higher than the number encountered in open air and is of the same order of magnitude as in indoor air $\left(10^{3}-10^{4} \mathrm{~m}^{-3}\right)$. The concentration of an inlet gas, which is highly contaminated with microorganisms, is considerably reduced by the filtration process. From this it is concluded that a biofilter may serve as a system of capture. On the other hand, there is an extra contamination by the filtration process at low gas inlet concentration. From this it is concluded that a biofilter may also serve as a source of emission.

The rate of the capture process is of first order in the microorganism concentration with a rate constant that can be derived from expressions for single particle target efficiency for the deposition of dust particles in granular bed filters. The rate of the emission process is assumed to be proportional to the gas velocity. On the basis of both mechanisms an expression has been derived for the concentration of bacterial germs in the outlet gas as a function of the gas velocity, that is confirmed by observations in the laboratory-scale filter bed.

\section{Acknowledgements}

The authors are indebted to the Dutch Ministry of Housing, Physical Planning and Environment for financial support of this research program and to Mr. A.H.C. van den Oever for his valuable comments. 


\section{References}

1. Klages, S.; Hatami, M.: Vergleichender Mikrobiologische Untersuchungen an Biofiltern zur Abgasreinigung. Diplomarbeit, Universität Stuttgart, März 1987

2. Kingston, D.: Selective media in air sampling, a review. J. Appl. Bact. 34 (1971) 221

3. Luckiesh, M.; Taylor, A. H.: Heating, piping, air-conditioning 19 (1947) 113

4. Bovallius, A.; Bucht, B.: Three year investigation of the natural airborne bacterial flora at four localities in Sweden. Appl. and Env. Micr. 35 (1978) 847

5. Elliot, L. F; Mc Calla, T. M.; Deshazer, J. A.: Bacteria in the air of housed swine units. Appl. and Env. Micr. 32 (1976) 270

6. Clark, C. S.; Rylander, R.; Larsson, L.: Levels of gram-negative bacteria, Aspergillus fumigatus, dust and endotoxin at compost plants. Appl. and Env. Micr. 45 (1983) 1501

7. Adams, A. P.; Spendlove, J. C.: Coliform aerosols emitted by sewage treatment plants. Science 169 (1970) 1218

8. Ladd, F. C.: Airborne bacteria from liquid waste treatment units. M.S. Thesis, Oklahoma State University, 1966

9. Verstraete, W.: Mededelingen faculteit landbouwwetenschappen Gent 39 no. 1 (1976) 259

10. Gaden, E. L.; Humphrey, A. E.: Fibrous filters for air sterilizations. Ind. and Eng. Chem. 48 (1956) 2173

11. May, K. R.; Marper, G. J.: The efficiency of various liquid impinger samples in bacterial aerosols. Brit. J. Industr. Med. 14 (1957) 287

12. Gutfinger, C.; Tardos, G. I.: Theoretical and experimental investigation on granular bed dust filters. Atm. Env. 13 (1979) 853

13. Lembke, L. L.; Kniseley, R. N.: Airborne microorganisms in a municipal solid waste recovery system. Can. J. Micr. 31 (1985) 198

14. Lembke, L. L.; Kniseley, R. N.; Van Nostrand, R. C.; Hale, M. D.: Precision of the all-glass impinger and the Andersen microbial impactor for air sampling in solid-waste handling facilities. Appl. and Env. Micr. 42 (1981) 222

15. Sorber, C. A.; Bausum, H. T.; Schaub, S. A.: A study of bacterial aerosols at a waste water irrigation site. Journal W.P.C.F. 48 (1976) 2367
16. Jones, W.; Morring, K.; Morey, P.; Sorenson, W.: Evaluation of the Andersen viable impactor for single stage sampling. Am. Ind. Hyg. Ass. J. 46 (1985) 294

17. Gillespie, V. V.; Clark, C. S.; Bjornson, H. S.; Samuels, S. J.; Holland, J. W.: A comparison of two-stage and six-stage Andersen impactors for viable aerosols. Am. Ind. Hyg. Assoc. J. 42 (1981) 858

18. Placencia, A. M.; Peller, J. T.; Oxborrow, G. S.; Danielson, J. W.: Comparison of bacterial recovery by Reuter centrifugal air sampler and slit-to-agar sampler. Appl. and Env. Micr. 44 (1982) 512

19. Friedlander, S. K.: Particle diffusion in low-speed flows. J. Colloid Interface Sci. 23 (1967) 157

20. Tardos, G.; Abuaf, N.; Gutfinger, C.: Diffusional filtration of dust in a fluidized bed filter. Atm. Env. 10 (1976) 389

21. Gutfinger, C.; Tardos, G. I.: Theoretical and experimental investigation on granular bed dust filters. Atm. Env. 13 (1979) 853

22. Paretsky, L.; Theodore, L.; Pfeffer, R.; Squires, A. M.: Panel bed filters for simultaneous removal of fly ash and sulphur dioxyde. J. Air Pollut. Control Ass. 21 (1971) 204

23. Gutfinger, C.; Tardos, G.; Abuaf, N.: Analytical and experimental studies on granular bed filtration. Proc. Symp. Transfer Util. Particulate Control Technol. 3 (1978) 243

24. Doganoglu, Y.; Jog, V.; Thambimuthu, K. V.; Clift, R.: Removal of fine particulates from gases in fluidised beds. Trans. I. Chem. E. $56(1978) 239$

25. Thambimuthu, K. V.: Gas filtration in fixed and fluidized beds. $\mathrm{Ph} . \mathrm{D}$. Thesis, Cambridge 1980

26. Ottengraf, S. P. P.; Van den Oever, A. H. C.: Kinetics of organic compound removal from waste gases with a biological filter. Biotechn. and Bioeng. 25 (1983) 3089

Received December 18, 1990

S.P. P. Ottengraf

University of Technology

Eindhoven

J. H. G. Konings

DSM Research

Geleen

The Netherlands 